\title{
'n Internasionale perspektief op die uitset van graduandi in Suid-Afrika
}

In die proses van al die veranderinge wat Suid-Afrika tans ondergaan, word baie dimensies van die samelewing indringend ondersoek. In die lig van die verdere ontwikkeling van die land is die uitset van graduandi 'n besonder belangrike dimensie vir kritiese ontleding. Ongelukkig ontbeer die debat oor hierdie aangeleentheid

\begin{tabular}{|c|c|c|c|}
\hline TABEL1 & \multicolumn{3}{|c|}{$\begin{array}{l}\text { Ewekniegroepe van lande aan die hand van die } \\
\text { BNP per capita } \\
\text { (": Lande op die grens van die onderskeie groepe } \\
\text { met ' } n \text { lae en 'n hoē uitset van graduandi) }\end{array}$} \\
\hline \multirow{2}{*}{$\begin{array}{l}\text { BNP } \\
\text { per capita }\end{array}$} & \multicolumn{3}{|c|}{ Lande } \\
\hline & \multicolumn{2}{|c|}{ Lae uitset van graduandi } & $\begin{array}{l}\text { Hoê uitset van } \\
\text { graduandi }\end{array}$ \\
\hline$<1000$ & $\begin{array}{l}\text { Benin } \\
\text { Burkina } \\
\text { Sjina* } \\
\text { Ghana } \\
\text { Honduras } \\
\text { Kongo } \\
\text { Lesotho } \\
\text { Malawi } \\
\text { Nigerië } \\
\text { PapuaNG } \\
\text { Senegal } \\
\text { Soedan } \\
\text { Swaziland } \\
\text { Togoland } \\
\text { Zambië }\end{array}$ & $\begin{array}{l}\text { Botswana } \\
\text { Burundi } \\
\text { Ethiopië } \\
\text { Guyana } \\
\text { Kenia } \\
\text { Laos } \\
\text { Madagaskar } \\
\text { Niger } \\
\text { Oeganda } \\
\text { Rwanda } \\
\text { Sentraal-Afrika } \\
\text { SriLanka } \\
\text { Tanzaniē } \\
\text { Zaïre } \\
\text { Zimbabwe }\end{array}$ & $\begin{array}{l}\text { Bangladesj } \\
\text { Sjina* } \\
\text { Egipte } \\
\text { Gaza-strook } \\
\text { Indonesiē } \\
\text { Mongoliē } \\
\text { Marokko } \\
\text { Nepal } \\
\text { Osmalië }\end{array}$ \\
\hline $\begin{array}{l}1000- \\
4000\end{array}$ & $\begin{array}{l}\text { Albanië } \\
\text { El Salvador } \\
\text { Gaboen } \\
\text { Jamaika } \\
\text { Maleisiē } \\
\text { Sirië } \\
\text { Thailand } \\
\text { Tunisiē } \\
\text { Uruguay }\end{array}$ & $\begin{array}{l}\text { Algerië } \\
\text { Fidji } \\
\text { Iran } \\
\text { Kameroen } \\
\text { Mauritius } \\
\text { Suid-Afrika } \\
\text { Trinidad \& } \\
\text { Tobago } \\
\text { Turkye } \\
\text { Venezuela }\end{array}$ & $\begin{array}{l}\text { Brasiliē } \\
\text { Chili } \\
\text { Colombiē } \\
\text { Costa Rica } \\
\text { Jordaniē } \\
\text { Kuba } \\
\text { Meksiko } \\
\\
\text { Thailand } \\
\text { Wes-oewer }\end{array}$ \\
\hline $\begin{array}{l}4000- \\
16000\end{array}$ & $\begin{array}{l}\text { Bahrein } \\
\text { Griekeland* } \\
\text { Hong Kong } \\
\text { Italiē } \\
\text { Malta } \\
\text { Portugal } \\
\text { Singapoer }\end{array}$ & $\begin{array}{l}\text { Barbados } \\
\text { Guam } \\
\text { Hongarye } \\
\text { Joego-Slawiē } \\
\text { Nieu-Caledoniẽ } \\
\text { Saoedi-Arabië } \\
\text { Spanje }\end{array}$ & $\begin{array}{l}\text { Australiē } \\
\text { Bulgarye } \\
\text { Griekeland* } \\
\text { lerland } \\
\text { Israel } \\
\text { Nieu-Seeland } \\
\text { Pole } \\
\text { Catar } \\
\text { Suid-Korea } \\
\text { Verenigde } \\
\text { Koninkryk }\end{array}$ \\
\hline$>16000$ & $\begin{array}{l}\text { Belgiē } \\
\text { Duitsland } \\
\text { Frankyk" } \\
\text { Koeweit } \\
\text { Oostenryk } \\
\text { Switserland }\end{array}$ & $\begin{array}{l}\text { Denemarke } \\
\text { Finland } \\
\text { Japan } \\
\text { Nederland } \\
\text { Swede } \\
\text { Verenigde } \\
\text { Arabiese Emirate }\end{array}$ & $\begin{array}{l}\text { Frankryk" } \\
\text { Kanada } \\
\text { Noonweē } \\
\text { VSA }\end{array}$ \\
\hline
\end{tabular}

dikwels die nodige realisme, aangesien simplistiese vergelykings tussen Suid-Afrika en lande soos die Verenigde Koninkryk en die Verenigde State van Amerika getref word. Hierby word die harde werklikheid van Suid-Afrika se agterstand en algemene ontwikkeling uit die oog verloor.

In 'n poging om die nodige perspektief te kry en hieruit 'n verantwoorde ontwikkelingsrigting af te lei, is 'n empiriese analise van die samehang tussen bruto nasionale produk per hoof van die bevolking (BNP per capita) en die relatiewe produksie van graduandi in die wêreld gedoen. (1) Daardie analise het 102 lande van die wêreld ingesluit - waarvoor ongelukkig slegs data tot 1989 beskikbaar was. Dié lande verteenwoordig $65 \%$ van die wêreldbevolking. Vir die huidige verkorte beskouing oor hierdie aangeleenthede, is die inligting sover as moontlik bygewerk.

By so ' $n$ beskouing is dit nodig om in ag te neem dat BNP per capita ' $n$ eenduidige betekenis het vir alle lande, maar dat die begrip "graduandus" beslis meerduidig is. In die volgende tabel is die moontlike verskille in dié begrip in ag geneem deur lande in elke interval van BNP per capita te verdeel in dié met ' $n$ lae uitset en dié met 'n hoë uitset. Tabel 1 rangskik die lande in ewekniegroepe ten opsigte van die twee dimensies BNP per capita en uitset in graduandi. Let op dat Suid-Afrika in die tweede ewekniegroep val.

Vir hierdie ewekniegroepe is die gemiddelde relatiewe uitset van graduandi oor die hele groep in die twee kategorieë "laag" en "hoog" vir elk van die groepe bereken. Die relatiewe syfer word gegee in getal graduandi per 10000 lede van die bevolking, en in tabel 2 gevind; met 'n grafiese voorstelling in figuur 1 .

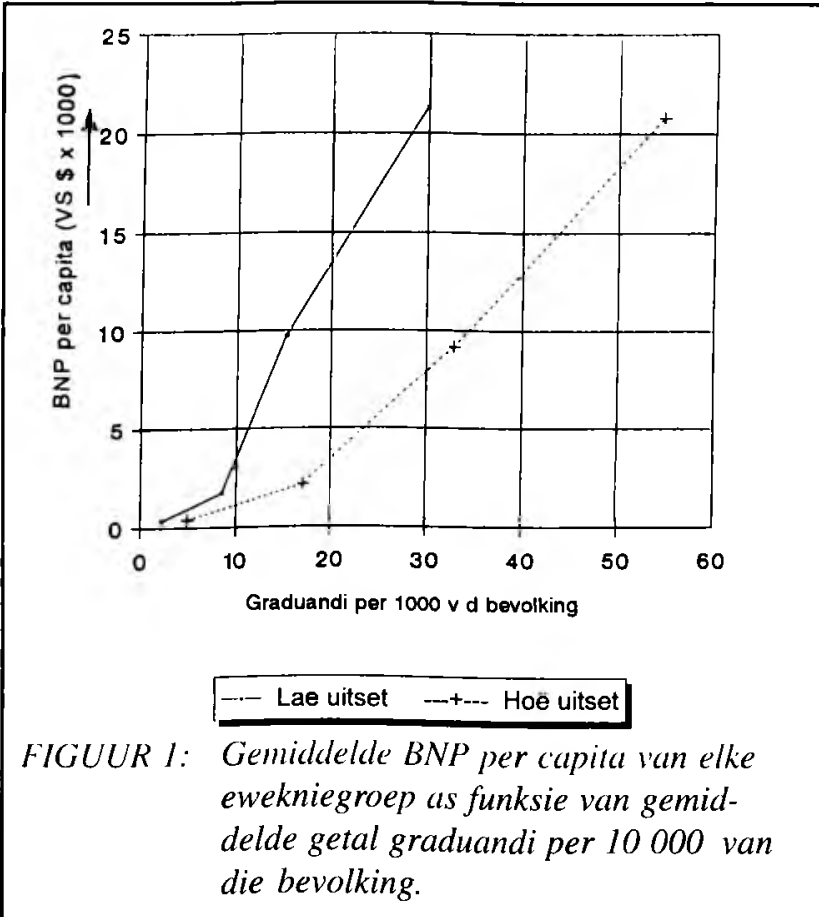




\begin{tabular}{|l|l|r|r|c|}
\hline TABEL2 & \multicolumn{4}{|l|}{$\begin{array}{l}\text { Uitset van graduandi per ewekniegroep as } \\
\text { funksie van BNP per capita }\end{array}$} \\
\hline $\begin{array}{l}\text { BNPper } \\
\text { capita }\end{array}$ & \multicolumn{3}{|c|}{$\begin{array}{l}\text { Gemiddelde uitset aan graduandi per 10 000 van die } \\
\text { bevolking en die ooreenkomstige gemiddelde BNP } \\
\text { per capita(US \$) van die betrokke ewekniegroep }\end{array}$} \\
\cline { 2 - 5 } & \multicolumn{3}{|c|}{ LAE UITSET } & \multicolumn{2}{|c|}{ HOê UITSET } \\
\hline & Graduandi & \multicolumn{1}{|c|}{$\begin{array}{l}\text { BNPper } \\
\text { capita }\end{array}$} & Graduandi & $\begin{array}{l}\text { BNPper } \\
\text { capita }\end{array}$ \\
\hline$<1000$ & 2,2 & 322 & 4,9 & 387 \\
$1000-4000$ & 8,5 & 1707 & 17,1 & 2140 \\
$4000-16000$ & 15,2 & 9731 & 32,9 & 9156 \\
$>16000$ & 29,8 & 21302 & 54,6 & 20794 \\
\hline
\end{tabular}

Vanuit die grafiese voorstelling van figuur 1 is enkele treffende afleidings moontlik:

1. Die benaderde reglynige verband tussen graduandi en BNP per capita is merkwaardig oor die hele bereik van ewekniegroepe onder die 102 lande wat ondersoek is.

2. Die grafiek toon ook dat, vir die laagste ewekniegroepe, is die invloed van die kleiner getal graduandi op die BNP per capita nie so betekenisvol as vir die lande wat hoër op lê nie. Die helling is kleiner, en gevolglik moet die uitset van graduandi per dollar van die BNP per capita hoër wees, totdat 'n kritiese getal graduandi bereik is.

3. Die analise illustreer die werklikhede van Suid-Afrika in die wêreld, met 8,27 graduandi per 10000 van die bevolking, met 'n BNP per capita van US $\$ 2460$. Dit onderstreep die onverstandigheid om Suid-Afrika byvoorbeeld met die VK te vergelyk - waar die ooreenkomstige syfers 33,13 en US $\$ 14570$ is.

4. Suid-Afrika is tans by die knakpunt op die kurwe, en moet ten alle koste nie terugsak nie, maar voorwaarts beweeg.

\section{WAARHEEN SUID-AFRIKA?}

Indien die samestelling van die graduandi in Suid-Afrika verder geanaliseer word in vergelyking met die lande in die ewekniegroep, word die gegewens soos in tabel 3 verkry. Alhoewel heelwat nog te sê val oor die kleiner verskille tussen ons land en die gemiddelde uitset van die ewekniegroep waarin ons is, is daar twee belangrike velde - dié van landbou en ingenieurswese - waarby ons ver agterloop by die ewekniegroep. Aangesien dit juis twee gebiede betref wat van deurslaggewende belang is vir verdere ontwikkeling, is hierdie vasstelling besonder ontstellend - veral as na die name van die lande in die eweknielys van Suid-Afrika gekyk word.

Oor die langer termyn word die posisie ten opsigte van die vereistes om uit die huidige ewekniegroep te groei in tabel 4 weergegee. Ten einde oor' $n$ periode van twintig jaar te groei na die breë per capita drempel (US \$4000) van die volgende ewekniegroep soos Australië, Israel, Nieu-Seeland en die Verenigde Koninkryk, sal 'n gemiddelde groei aan uitset van graduandi van $2,4 \%$ per jaar gehandhaaf moet word. Hierdie verwagting is redelik, aangesien onlangse analise aandui dat hierdie groeitempo gehandhaaf is oor die tydperk 1989 tot 1992

\begin{tabular}{|c|c|c|c|}
\hline \multirow{4}{*}{$\begin{array}{l}\text { TABEL3 } \\
\text { BREË } \\
\text { STUDIEVEDD }\end{array}$} & \multicolumn{3}{|c|}{$\begin{array}{l}\text { gelyking van die graduandi-samestelling van } \\
\text { d-Afrika met die gemiddelde van sy } \\
\text { eknielande }\end{array}$} \\
\hline & \multicolumn{3}{|c|}{$\begin{array}{l}\text { Graduandi per } 10000 \text { van die bevolking } \\
\text { (basisjaar 1989) }\end{array}$} \\
\hline & \multirow{2}{*}{$\begin{array}{l}\text { Gemiddelde vir } \\
\text { ewekniegroep }\end{array}$} & \multicolumn{2}{|c|}{ SUID-AFRIKA } \\
\hline & & $\begin{array}{l}\text { Werklike } \\
\text { uitset }\end{array}$ & $\begin{array}{l}\text { Persentasievan } \\
\text { gemiddelde vir } \\
\text { ewekniegroep }\end{array}$ \\
\hline $\begin{array}{l}\text { Geestes-en } \\
\text { Menswetenskappe }\end{array}$ & 5,30 & 5,83 & 110 \\
\hline $\begin{array}{l}\text { Regteen } \\
\text { Bestuurswese }\end{array}$ & 1,50 & 1,88 & 125 \\
\hline Ander & 3,80 & 3,95 & 104 \\
\hline Natuurwetenskappe & 3,15 & 2,44 & 77 \\
\hline Gesondheid & 1.09 & 0,94 & 86 \\
\hline Ingenieurswese & 0,92 & 0,42 & 46 \\
\hline Landbou & 0,39 & 0,20 & 52 \\
\hline Ander & 0,76 & 0,20 & 115 \\
\hline TOTAAL & 8,46 & 8,27 & 98 \\
\hline
\end{tabular}

\begin{tabular}{|c|c|c|c|}
\hline \multirow{3}{*}{$\begin{array}{l}\text { TABEL4 } \\
\text { BREë } \\
\text { STUDIEVED }\end{array}$} & \multicolumn{3}{|c|}{$\begin{array}{l}\text { Geprojekteerde groei vir Suid-Afrika om by } \\
\text { die volgende hoër ewekniegroep van lande } \\
\text { aan te sluit in } 20 \text { jaar }\end{array}$} \\
\hline & \multicolumn{3}{|c|}{ Graduandi per 10000 van die bevolking } \\
\hline & \multicolumn{3}{|c|}{ SUID-AFRIKA } \\
\hline & $\begin{array}{l}\text { Werklik } \\
1992\end{array}$ & $\begin{array}{l}\text { Doelwit } \\
2012\end{array}$ & $\begin{array}{l}\text { Nodige } \\
\text { jaarlikse groei } \\
\text { vir doelwit }\end{array}$ \\
\hline $\begin{array}{l}\text { Geestes- en } \\
\text { Mensweten- } \\
\text { skappe }\end{array}$ & 6,70 & 9,07 & $1,5 \%$ \\
\hline Regte, Bestuur & 2,32 & 2,91 & $1,1 \%$ \\
\hline Ander & 4,38 & 6,16 & $1,7 \%$ \\
\hline $\begin{array}{l}\text { Natuurweten- } \\
\text { skappe }\end{array}$ & 2,38 & 5,49 & $4,3 \%$ \\
\hline Gesondheid & 0,91 & 0,94 & $0,2 \%$ \\
\hline Ingenieurswese & 0,44 & 1,92 & $7,6 \%$ \\
\hline Landbou & 0,11 & 0,56 & $8,5 \%$ \\
\hline Ander & 0,92 & 2,07 & $4,1 \%$ \\
\hline TOTAAL & 9,08 & 14,56 & $2,4 \%$ \\
\hline
\end{tabular}


Hierdie groei was egter volledig beperk tot die Geestesen Menswetenskappe, sodat dit die nodige, baie hoë groei van $7,6 \%$ en $8,4 \%$ per jaar in ingenieurswese en landbou oor die volgende 20 jaar net meer beklemtoon.

In antwoord op die vraag: "Waarheen Suid-Afrika", moet dus as 'n begin - ten opsigte van drie lewensbelangrike dimensies - geantwoord word:

(a) Suid-Afrika is op belangrike gebiede uit pas met selfs die relatief onderontwikkelde lande in sy ewekniegroep. Die wanpas is in gebiede wat baie belangrik is vir verdere ontwikkeling, naamlik landbou en ingenieurswese. Daar is 'n indringende noodsaak om deur verskuiwing van aksente hierdie wanbalans ten opsigte van sy eweknielande (onderontwikkeld) reg te stel.

(b) Indien Suid-Afrika wens om die vrugte van verhoogde uitset aan graduandi as deel van die uitset aan menslike hulpbronne te benut om sy mededingende posisie internasionaal te verbeter, moet aan die vereiste relatiewe groeitempo van $2,4 \%$ per jaar oor die volgende twintig jaar voldoen word. Dit sal hom laat groei tot by die drumpel van die volgende portuurgroep van lande.

(c) In hierdie groeiproses na 'n volgende hoër ewekniegroep, is 'n ongekende poging nodig om 'n baie hoë groeikoers van meer as $7 \%$ per jaar aan menslike hulpbronne oor twintig jaar in die velde van landbou en ingenieurswese te handhaaf. Dit is van deurslaggewende belang dat hierdie inset deurgevoer word na huidige prosesse vir verandering.

(d) Die bogenoemde aanbevelings berus op gegewens uit ' $n$ empiriese analise. Die verdere - baie nodige - kritiese empiriese studies om meer besonderhede bloot te lê, is broodnodig en moet onverwyld aangepak word.

C.F. CROUSE

\section{LITERATUURVERWYSING}

1. Crouse, C.F. (1993). Die lewering van graduandi in Suid-Afrika: 'n portuurgroepvergelykenis, Aambeeld, 21(2), pp. 26-31. 